\title{
Effect of Invasive Pest Phenacoccus manihoti Matile-Ferrero (Hemiptera; Pseudococcidae) in
} Cassava

\author{
Nila Wardani ${ }^{1}$, Aunu Rauf ${ }^{2}$, I Wayan Winasa ${ }^{2}$, Sugeng Santoso ${ }^{2}$ \\ ${ }^{1}$ Lampung Assesment Institute for Agriculture Technology, Jl. ZA. Pagar Alam No. IA, Bandar Lampung, \\ email: wardaninila@yahoo.co.id \\ ${ }^{2}$ Department of Plant Protection, Bogor Agricultural University, Dramaga Campus, Bogor, West Java, Indonesia 16680
}

\begin{abstract}
Heavy damage by the cassava mealybug, Phenacoccua manihoti Matile-Ferrero (Hempiptera: Pseudococcidae) caused symptoms of bunchy top, shortened and distorted nodes, leaf drops, and inhibition of plant growth. The consequences of these pests can cause yield losses of $80 \%$. This study was to determine the development of P. manihoti and cassava yield loss. Field observations indicated that symptoms of bunchy top appeared as early as 8 weeks after planting (wap) and rose quickly started 16 wap, at the same time with the advent of the dry season (May-June). Level of infestation developed faster on variety Jimbul; at 18 wap all plants had bunchy tops. While on varieties Roti and Manggu, 100\% infestation occurred at 30 and 36 wap, respectively. There was a correlation between early infetation with plant height ang yield. Cassava plants infested during early stage were shorter and the yield lower, compared to those infested at further stages. Lower yields of variety Jimbul (0.94 kg/tree) than variety Manggu (3.16 kg/plant), was thought to be related to heavy infestation which occurred during early stage.
\end{abstract}

Keywords - Cassava, mealybug, level of infestation, Phenacoccus manihoti..

\section{INTRODUCTION}

Plant lice from the family Pseudococcidae are often referred to as mealybug. Damage to plants by these pests due to stilet suction on the leaves can cause leaf wrinkles, some types can act as vectors of plant viruses or cause chlorosis due to the presence of saliva (saliva) which is toxic $[1,2]$.

Plant lice often invade previously uninfested areas by sending plant material from one area to another. Population explosions often occur if they are not accompanied by natural enemies or there are no natural enemies in new areas. The population will remain stable in new areas because of the control of natural enemies both predators and parasitoids [1]. The important role of the natural enemy of white lice has been widely reported in the Americas and Africa [3, 4, 5].

One of the mealybug pests that attack cassava plants in Indonesia is $P$. manihoti. $P$. manihoti came from South America and entered Africa in the 1980s. This pest first entered the Southeast Asian region was Thailand in 2009, which caused heavy attacks, possibly having spread to Laos and Cambodia. In Indonesia it was first discovered in the West Java area at the end of $2010[6,7]$.

Adult $P$. manihoti is oval in shape, pink in color covered with waxy white flour, body size is more or less long
$(1.10-2.6 \mathrm{~mm})$ and wide $(0.50-1.40 \mathrm{~mm})$ [8]. Often found at the top of the plant which results in the tops becoming wrinkled and dwarfing bunchy tops. Heavier attacks occur in the dry season than in the wet season [9]. In Colombia $P$. manihoti and $P$. hereni can cause a $68-88 \%$ reduction in production and in Africa can cause yield losses of up to $80 \%$ [10].

It is known that in Asia, Indonesia is one of the biggest cassava producers after Thailand [11]. In the country, cassava is widely used as raw material for food and nonfood industries. Currently, in addition to food and feed, cassava can be developed as an alternative energy source (biofuel). By using bioethanol as a premium mixture (Premium mix E 10) for transportation. Bioethanol is sourced from starchy and sugary plants such as corn, cassava, sweet potatoes, sago and sugar cane. Production costs for each liter of ethanol from cassava are cheaper compared to other raw materials so that the development of cassava-based industries is quite prospective [12].

Although in Indonesia the level of damage and severe attacks have never been reported, but this pest has the potential to cause cassava yield loss if not controlled. For this reason, this study aims to determine the development of $P$. manihot $i$ attacks, cassava losses due to these pests. 


\section{METHODOLOGY}

The study was conducted on farmers' land in the villages of Ngampar, Cikeas and Sukaraja, Sukaraja District. The research took place from February 2012 to February 2013. The level of attack is known to be taken as a sample in the form of 10 plots of cassava plantations taken by purposive sampling in each village (Ngampar, Cikeas, and Sukaraja). From each plot of cassava plantations 20 samples were observed, with diagonal sampling technique. Then observed plants that were attacked by $P$. manihoti, and which were not attacked

Observation of the level of attacks carried out in the garden of cassava farmers in the village of Ngampar which has been attacked by the pest $P$. manihoti. The area of farmers' gardens that was used as observation plots ranged from 1000-2000 m2. Observations were made on three types of local cassava varieties namely Bread, Manggu and Jimbul varieties. The population of each cassava variety that was chosen as the selected sample was Bread variety with a total population of 1504 plants, 472 Manggu plants and Jimbul 629 plants. Cultivation techniques are applied in accordance with what is done by farmers, namely monoculture cultivation with a spacing of $1 \mathrm{~m} \mathrm{x} 1 \mathrm{~m}$, fertilizing is done using manure and urea fertilizer. The plantations observed were not applied with pesticides.

Observations to determine the development of P. manihoti attacks on cassava plants (rainy season and dry season) were carried out on all plant populations with observational intervals every two weeks. The initial effect of white lice infestation on the production and observation of natural enemies was carried out on 40 plant samples for each observed variety, with observational intervals once every two weeks. The observations were tabulated and the tendencies compared between the three varieties observed.

\section{P. manihoti survey}

\section{RESULTS AND DISCUSSION}

The attack from $P$. manihoti at three locations in Sukaraja District was very high. The highest attacks occurred in Sukaraja Village $99.5 \%$ and Ngampar Village $(99.4 \%)$, the lowest in Cikeas Village (73.5\%). Although different, but the level of attacks in this district is relatively the same as the average attack of almost one hundred percent.

The difference in the level of $P$. manihoti attacks can be caused by several factors. Like most insect pests, mealybug population dynamics are influenced by biotic and abiotic factors that will shape the characteristics of pest populations, such as density, rate of birth, rate of death, distribution pattern, biotic potential, and behavior [13]. One of the abiotic factors that affect mealybug populations is environmental conditions such as climate, especially rainfall, temperature and humidity. The population is strongly influenced by climatic conditions so that population abundance is higher in arid regions compared to areas with high rainfall (wet) [9]. Hotter conditions with lower humidity, is a more suitable place for the development of P. manihoti. The high attack from mealybug is seen with the symptoms of banchy top and stem distortion.

\section{Increased symptoms of $\boldsymbol{P}$. manihoti attacks}

Observation of the development of $P$. manihoti attacks begins when the plants are 6 weeks after planting (wap) until the plants are harvested. In the field, all varieties appear to show symptoms of attack, but differ in severity and severity of symptoms of attack (Figure 1). This condition shows that there are differences in the resistance of the three cassava varieties observed, as well as the results of the study of the resistance of 4 cassava varieties in Thailand, between the Kasetsart 50 varieties, Huaybong 60, Rayong 9 and Rayong 72, all varieties attacked by $P$. manihoti, differences occur at the level of pest attacks [14].

The development of $P$. manihoti is strongly influenced by environmental factors, especially rainfall. Figure 2 presents the rainfall that took place during the study. Attacks increase rapidly starting in June, or after the plants are 15 weeks after planting (wap), and reach a peak in September / October. The relatively hot temperature and low rainfall during this period caused the population of $P$. manihoti to develop faster, especially in Pseudococcidae [15].

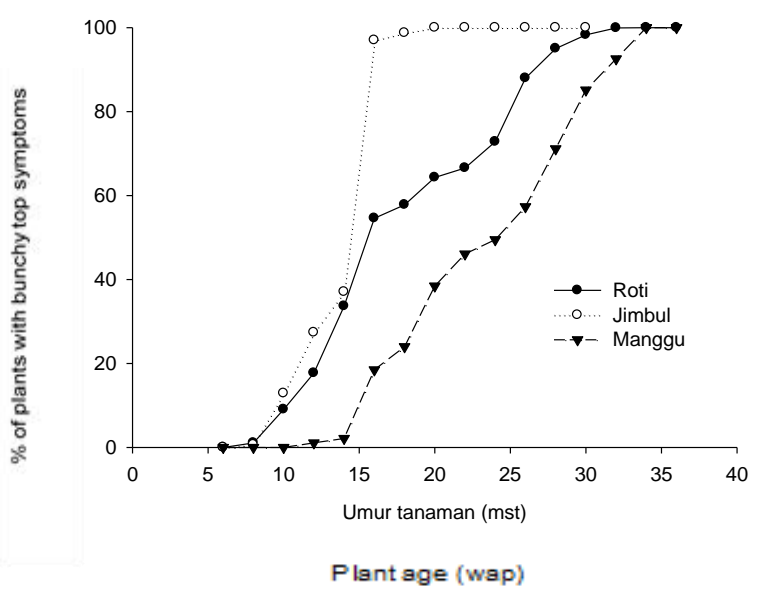

Fig.1: Development of $P$. manihoti's attack on three cassava varieties 


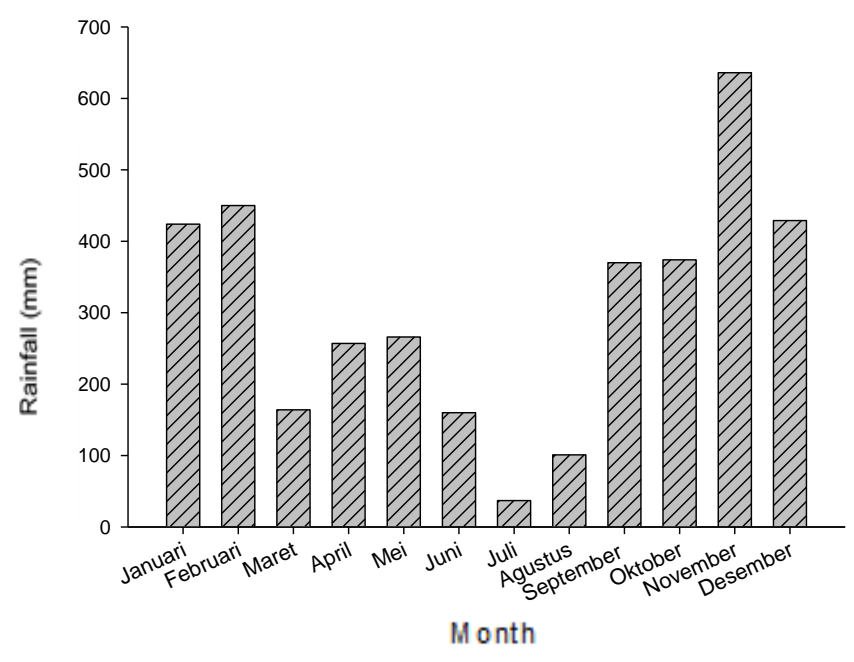

Fig.2: Rainfall around the study site [16]

P. manihoti attacks begin with the symptoms of an initial attack, where the shoots of the cassava plants begin to wrinkle, the initial symptoms usually occur around 7-10 days, then with an increase in the flea population, the symptoms of the attack quickly become a bunchy top, ie, the shoots wrinkle and collect. This symptom lasts relatively long (20-30 days). When lice reach a high population (approximately 200-1000 individuals in one shoot), then the shoots of plants will lose leaves (deciduous leaves). The shoots will remain leafless until it rains. If it rains, it will re-sprout at the top of the plant, due to lice attack will leave the trunk with a short internode or like a wrinkle, sometimes even the stems become bent and curved, this phenomenon is known as distortion on the stem. This distortion can be seen along the stems of cassava plants and can indicate how many times there was an attack on a cassava tree during its growth period.

The lowest attack rate occurred around November to February, at this time it was seen that the intensity of rainfall that occurred was quite high at $429-636 \mathrm{~mm} /$ month [16]. The presence of rain that falls almost every day in these months causes lice in plants to be carried mechanically by rainwater and die, so the population is decreasing. With the rain, the shoots of the cassava plants that have fallen leaves sprout again.

The mechanism of the death of plant lice in the presence of rain water can be used as an idea to control lice using water such as falling rain using sprinklers. The principle used by this system is to put pressure on the water in the pipe and emit it into the air so that it resembles the rain that then falls on the surface of the soil or plants.

For cassava irrigation has not been done much, but with the increasingly high economic value of cassava, the provision of irrigation either by drip irrigation or sprinkler may be developed, and irrigation by using sprinkler is an alternative that can be used. Because besides being able to provide irrigation to plants but it can also function mechanically to reduce the isolation of white lice. In this case research on discharge, the water pressure needed to be able to reduce the flea population with sprinkler irrigation remains to be done. Watering aims to provide additional water to rainwater in sufficient time and when plants are needed. In general, irrigation is useful for facilitating soil management, regulating soil temperature and microclimate, cleaning or washing the soil of dissolved salts or high acids, cleaning dirt or garbage in waterways, and inundating the soil to eradicate pests and pests disease [17].

The three varieties observed were local varieties, but only the Manggu variety had clear origins. The other two varieties are unclear, but their characteristics can be approached with varieties that have been released by the Ministry of Agriculture. Roti varieties tend to be the same as Adira-4, and Jimbul is closer to Malang-2 varieties. Manggu variety is produced by the cassava plantation in Lido, Cijeruk, Bogor, which is capable of producing 80120 tons / ha, with an age of 11 months and 32\% starch.

Three varieties were observed, the difference in the level of attack occurred mainly due to the initial difference in the occurrence of the attack, and the speed at which the attack developed, until all plants were attacked $100 \%$ (Figure 1). The average initial occurrence of mealybug attacks in Roti and Jimbul varieties is at the age of 8 wap, while Manggu varieties at 12 wap, the attack rate increases with increasing age of the plant. From Figures 1 and 2 it is also seen that the peak of $P$. manihoti's attack on the Roti variety occurred around September, the Jimbul variety in June to July, and the Manggu variety in October. It can be seen that Jimbul varieties are relatively vulnerable to dry conditions due to low rainfall which causes the plants to be heavily attacked. In the Roti and Manggu varieties at the peak of the dry season, they are better able to survive so that new plants are attacked one hundred percent when the rainy season.

The rate of increase in attacks differs from the three varieties. From Figure 1, it can be seen that for Roti and Manggu varieties the rate of attack development is relatively constant, but in Jimbul varieties there is a surge in the development of attacks when the plant ages 14-16 wap. In Roti and Manggu varieties, the entire plant population was attacked when the plant was older than 34 wap, whereas in Jimbul varieties at 18-20 mst the entire plant population was attacked by $P$. manihoti. From the physical symptoms in the field it was also seen that the 
Jimbul variety showed more severe symptoms of attack compared to the other two varieties. Severe attacks (bunchy top) on the Jimbul variety occur at the age of 18 wap, on the Roti and Manggu varieties slower ie at 28 and 38 wap respectively. In Figure 1 it also appears that the Manggu variety experienced a slower initial attack compared to the other two varieties, which occurred at 16 wap, while at the same time the other two varieties increased the development of the attack.

From the physical structure, the three plant varieties are not much different, as are the cyanide acid $(\mathrm{HCN})$ content in plants. Laboratory test results of the Post-Harvest Agricultural Research and Development Center, Agricultural Research and Development Agency are known HCN levels of each variety below 50 ppm, Manggu varieties (31.20 mg / kg), Jimbul (32.06 mg / kg), and Roti (44.85 mg / kg). Cyanide acid compound is a secondary compound found in phloem from cassava plants, as it is known that phloem is the tissue where P. manihoti's white mites suck up liquid for consumption as nutrients. Cyanide acid compounds influence the development and reproduction of $P$. manihoti, so that with different rates of development and reproduction of these ticks in each cassava variety will affect the level of resistance of a cassava variety to $P$. manihoti. In this pest the secondary compound cyanide acid acts as a stimulant for its growth and development $[18,19]$. Cassava varieties with higher HCN levels are preferred by P. manihoti for their growth and development. High levels of cassava HCN cause P.manihoti to develop better, causing the plant to suffer more damage due to a higher flea population. Roti on differences in the content of cyanide acid compounds from the three observed varieties, Manggu varieties with lower $\mathrm{HCN}$ content appear to be more able to survive, and Jimbul and Roti varieties are more susceptible to $P$. manihoti attacks.

Many factors affect the growth and development of an insect both physical and chemical factors. Physical factors include the structure of the host plant, temperature and humidity, chemical factors including nutrient content and secondary compounds present in plants [20]. Physical factors, such as leaf surface structure, do not play an important role in the selection or preference of $P$. manihoti on cassava plants. The presence or absence of hair on the leaf surface is not related to its preference for the cassava host plant [21]. The colonization of cassava plants by $P$. manihoti was more influenced by the content of cyanide acids found in leaves, stems and roots [22, 23, 24].

$P$. manihoti causes damage to the leaves, so that it will affect the resulting tubers due to leaf surface reduction and even leaf depletion causing reduced photosynthetic reactions needed for tuber formation [25], as a result can cause yield losses of up to $90 \%$ (cassava) [10].

Overall, it can be seen that the Manggu variety shows better endurance compared to the other two varieties, resulting in higher tubers. Jimbul varieties that experience the most severe attack symptoms produce fewer tubers. The severity of the damage that occurs in Jimbul varieties, in addition to higher HCN levels, is also due to the relatively slow planting of the other two varieties. Jimbul varieties are planted near the dry season (low rainfall) so that when a severe attack occurs (June), the plants are still younger.

There are differences in the level and pattern of attacks, resulting in differences in yield per tree and total yield per hectare. The results of the weighing showed that of the three cassava plantations that had been attacked by P. manihoti, the highest tuber production of Manggu variety was on average $3.16 \mathrm{~kg} /$ tree (31.6 tons / ha) and significantly different compared to Jimbul variety with an average of $0.94 \mathrm{~kg} /$ trees ( 9.4 tons / ha).

\section{Effect of Attack Time on Plant Height and Weight of Bulbs}

The average height of plants at harvest and the weight of tubers produced per tree are related to the time of the attack (Figure 3). Severe attacks result in plants experiencing disruption in its growth. In the three plant varieties the same tendency was seen, cassava plants which were attacked earlier showed more inhibited growth compared to plants that were attacked at a later age. Stunted growth causes production per tree is also different. Plants that are attacked early by $P$. manihoti at the age of 2-12 wap, the resulting tubers are much reduced by an average of $1.5 \mathrm{~kg}(+70 \%)$ from the average normal production without pests (reaching $5 \mathrm{~kg} /$ tree). This reduction continues, until the initial attack by pests occurs at the age of 24 wap, which produces an average of $2.9 \mathrm{~kg}$ / tree $(+42 \%)$. The reduction in tuber production is relatively lower if the attack occurs after the plants are 24 wap with an average of $3.27 \mathrm{~kg} /$ tree $(+30 \%)$. 


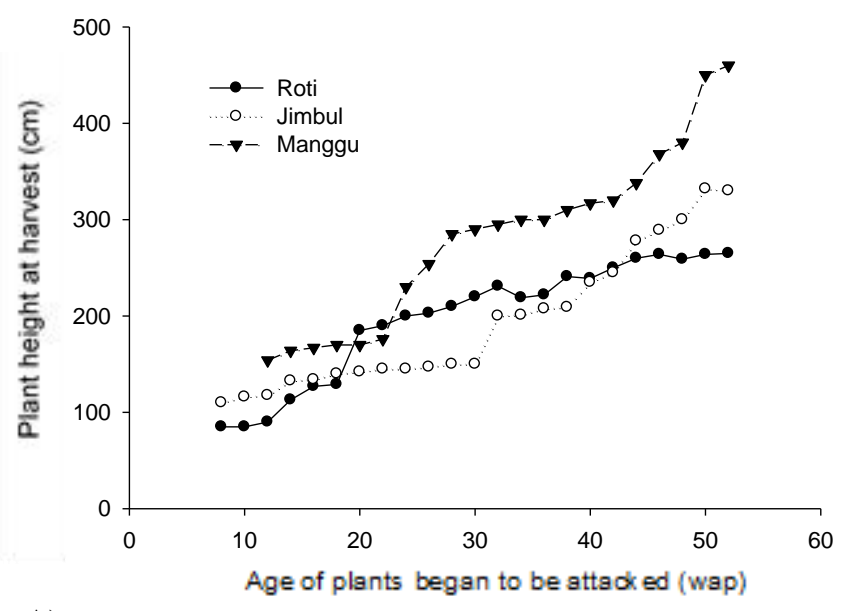

A)

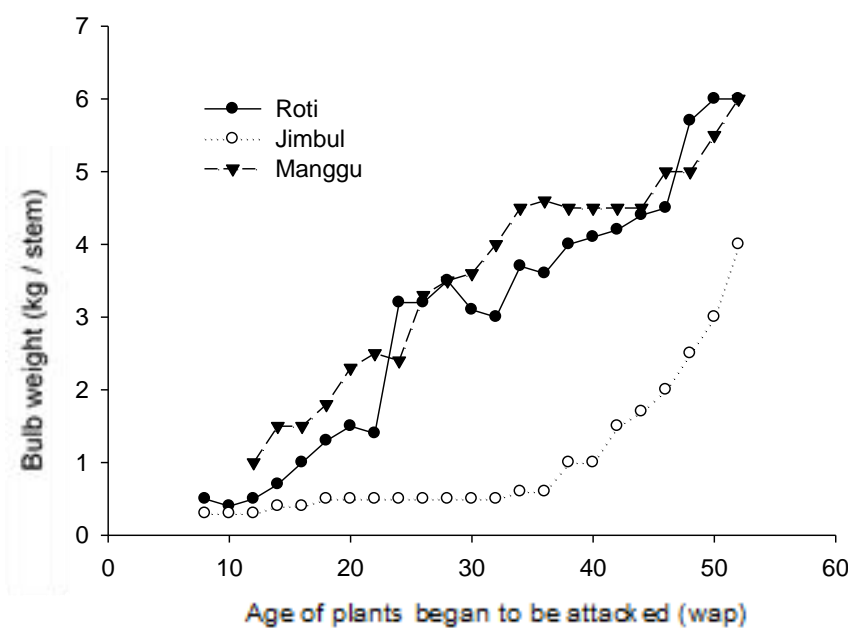

B)

Fig.3: Relationship between time of attack with plant growth (A) and tuber weight (B)

The tuber weights per stem between plants that the initial attack occurred at a young age were significantly different from the tuber weights if the plants were attacked at a later age. The sharp decrease in production of plants attacked at the beginning of growth occurs because the initial attack occurs at a critical phase of the cassava plant (4-12 mst) [26]. In this phase, the plant undergoes an early phase of leaf growth and root system formation, and some photosynthates that are not used for growth are stored in thetuber. Thus, disturbance to the leaves will cause a significant decrease in photosynthate yield. The attack at the beginning of growth causes disruption to plant growth so that plants are shorter than normal plants. Age 12-24 wap is the phase of stem and leaf growth, at this time the maximum growth rate of leaves and stems, tubers continues to grow, and the most active vegetative growth occurs during this period [26]. P. manihoti attack in this phase will greatly affect plant growth and tuber production. There is a relationship between plant height at harvest from affected plants and yields (Figure 4). Shorter plants due to $P$. manihoti when they are young produce much lighter tuber weights. While tall plants, because the attacks occur later, produce normal tuber weights.

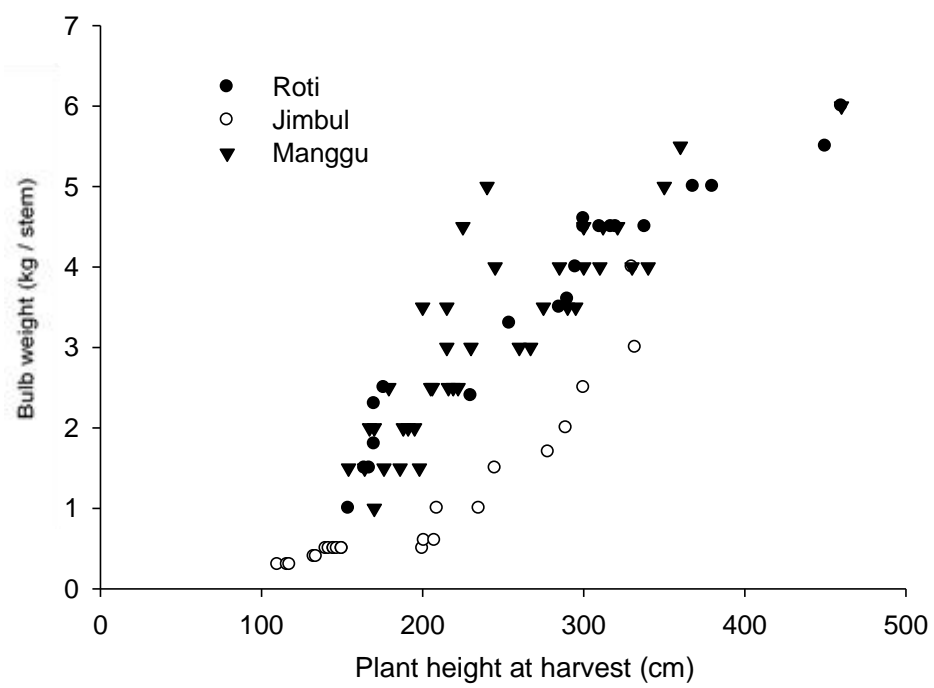

Fig.4: Relationsnip velween pıanı neıgnı a narvest and tuber weights

The high yield reduction in cassava plants that are attacked at a young age, then to reduce yield losses due to $P$. manihoti attacks, planting time should be adjusted at the beginning of the rainy season so that cassava plants avoid pests at the beginning of its growth. Likewise with the existence of $P$. manihoti's primary feeding properties on cassava, then to break the food chain of pests, simultaneous planting on a stretch can suppress population development.

\section{CONCLUSION}

Severe attacks of $P$. manihoti can cause symptoms of bunchy top, short and crooked books, deciduous leaves, and stunted plant growth. Attacks can occur since the plant is still young, and increase rapidly during the dry season with a peak occurring in September-October. The attack rate of $P$. manihoti in Jimbul varieties is heavier than in Roti and Manggu varieties. As a result, tuber weights produced by Jimbul varieties are lower. There is a pattern of the relationship between the initial attack occurs with the resulting tuber weights. Cassava plants that are attacked since young produce lower tuber weights, compared to when the attacks occur after the plants are older. 


\section{REFERENCES}

[1] William DJ, Willink MCG. 1992. Mealybugs of Central and South America. Willingford: CAB International.

[2] Ben-Dov Y, Hodgson CJ. 1997. Their Biology, Natural Enemies and Control, Armoured Scale Insects, Vol 4B. Amsterdam: The nederlands.

[3] Van Driesche RG, Bellotti AC, Castillo JA, Herrera CJ. 1990. Estimating total losses from parasitoids for a field population of a countinously breeding insect, cassava mealybug, Phenacoccus herreni (Homoptera : Pseudococcidae) in Colombia, S.A. Florida Entomologist. 73: 133-143.

[4] CIAT 1990. Annual Report Cassava Program 1989, CIAT Calt. Colombia.

[5] Neuenschwander P. 2004. Harnessing nature in Africa: biological pest control can benefit the pocket, health and the environment. Nature. 432: 801-802.

[6] Muniappan R, Shepard BM, Watson W, Carner GR, Rauf A, Sartiami D, Hidayat P, Afun JVK, Goergen G, Ziaur Rahman AKM. 2011. New Records of Invasive Insects (Hemiptera:Sternorrhyncha) in Southeast Asia and West Africa. J Agric Urban Entomol. 26(4):167-174.

[7] Rauf A. 2011. Invasive pests. IPM CRSP Annual Report 2010-2011.

[8] Matile-Ferrero D, 1978. Cassava mealybug in the People's Republic of Congo. In: Nwanze KF, Leuschner K, ed. Proceedings of the International Workshop on the cassava mealybug Phenacoccus manihoti Mat.-Ferr. (Pseudococcidae) held at INERA-M'vuazi, Bas-Zaire, Zaire, June 26-29, 1977. International Institute of Tropical Agriculture. Ibadania Niger, 29-46.

[9] James B, Yaninek J, Neuenschwander P, Cudjoe A, Modder W, Echendu N, Toko M. 2000.Pest Control in Cassava Farms. International Institute of Tropical Agriculture. 36p.

[10] Herren HR, Neuenschwander P. 1991. Biological control of cassava pest in Africa. Annu Rev Entomol. 36: 257283.

[11] Heriyanto, Krisdiana R, Anindita R. 2009. Prospek produk olahan ubikayu di pasar internasional dalam Ubikayu Inovasi Teknologi dan Kebijakan Pengembangan. Badan Litbang Pertanian. Pusat Peneltian dan Pengembangan Tanaman Pangan. $363 \mathrm{~h}$.

[12] Rozi F, Heriyanto. 2009. Ubikayu sebagai komoditas ekonomi dalam Ubikayu Inovasi Teknologi dan Kebijakan Pengembangan. Badan Litbang Pertanian. Pusat Peneltian dan Pengembangan Tanaman Pangan. $363 \mathrm{~h}$.

[13] Tarumingkeng RC. 1994. Dinamika Populasi Kajian Ekologi Kuantitatif. Jakarta: Pustaka Sinar Harapan \& Universitas Kristen Krida Wacana. $284 \mathrm{hlm}$.

[14] Soysouvanh P, Siri N. 2013. Population abundance of pink mealybug, Phenacoccus manihoti on four cassava varieties. Khon Kaen Agr J. 41(1):149-153.

[15] Walton VM, Daane KM, Pringle KL. 2004. Monitoring Planacoccus ficus in South African vineyards with sex pheromone-baited trap. Crop Protect. 23: 1089-1096.
[16] [BMKG] Badan Meteorologi Klimatologi dan Geofisika Stasiun Klimatologi Darmaga Bogor. 2013. Data temperatur dan curah hujan tahun 2012 daerah Katulampa. BMKG 6 Maret 2013. Bogor.

[17] Kurnia U. 2004. Prospek Pengairan Pertanian Tanaman Semusim Lahan Kering. Jurnal Litbang Pertanian. 23(4):130-138

[18] Calatayud PA, Rahbé Y, Delobe1 B, Khuong-Huu E, Tertuliano M, Le RÜ B. 1994. Infhence of secondary compounds in the floem sap of cassava on expressionof antibiosis towards the mealybug Phenacoccus manihoti. Entomol exp appl. 72: 47-57.

[19] Fraenkel, G., 1969. Evaluation of our thoughts on secondary plant substances. Entomol exp appl. 12: 473-486.

[20] Bernay EA, Chapman RF. 1994. Host-plant selection by phytophagous insects. Chapman \& Hall. 312 hal.

[21] Catalayud PA, Le RU B. 2006. Cassava-Mealybug interactions. Paris. $112 \mathrm{p}$.

[22] Arihantana M B, Buckle KA. 1986.Effect of non-enzymic browning, starch and sugars on total cyanide determination in cassava by an enzymatic assay. J Food Sci Tech. 21: 189-197.

[23] Ezeala D O, Okoro N. 1986. Processing techniques and hydrocyanic acid content of cassava-based human foodstuffs in Nigeria. J Food Biochem. 10: 125-132.

[24] Pancoro A, Hughes MA. 1992. In-situ localization of cyanogenics-glucosidase (linamarase) gene expression in leaves of cassava (Manihot esculenta Crantz) using nonisotopicriboprobes. Plant J. 2: 821-827.

[25] Tonglum A, Suriyanapan P, Howeler RH. 2001. Cassava agronomy research and adoption of improved practices in Thailand - Major achievement during the past 35 years. Cassava's Potential in Asia in the 21st Century: Present Situation and Future Research and Development Needs. Proc. of the Sixth Regional Workshop held in Ho Chi Minch City, Vietnam. 228-258.

[26] Wargiono J, Kartika, Solihin. 2009. Areal pertanaman dan sistem produksi dalam Ubikayu Inovasi Teknologi dan Kebijakan Pengembangan. Badan Litbang Pertanian. Pusat Peneltian dan Pengembangan Tanaman Pangan. $363 \mathrm{~h}$. 